\title{
The COVID-19 impact crisis communication model using gending jawa local wisdom
}

\author{
Puji Lestari ${ }^{\mathrm{a}, 1, *}$, Sularso ${ }^{\mathrm{b}, 2}$ \\ a Universitas Pembangunan Nasional "Veteran" Yogyakarta, Jl. SWK Jl. Ring Road Utara No.104, Ngropoh, Condongcatur, Kec. Depok, Kabupaten \\ Sleman, Daerah Istimewa Yogyakarta, 55283, Indonesia \\ b Universitas Ahmad Dahlan Yogyakarta, Jl. Kapas No.9, Semaki, Kec. Umbulharjo, Kota Yogyakarta, Daerah Istimewa Yogyakarta 55166, Indonesia \\ ${ }^{1}$ puji.lestari@upnyk.ac.id; ${ }^{2}$ sularso@pgsd.uad.ac.id; \\ * corresponding author
}

ARTICLE INFO

Article history

Received 2020-06-07

Revised 2020-06-08

Accepted 2020-06-15

Keywords

Crisis Communication Model

COVID-19

Local Wisdom

Gending Jawa

Sanggar Seni Rasa Jati

\section{ABSTRACT}

Pandemic COVID-19 is a new epidemic that is sweeping the world with a high level of fatal potential. The role of communication is vital as a response to global health disasters. Thus, the communication network and information dissemination process about COVID-19 need to be expanded as a disaster mitigation effort. The question is how information dissemination can be done, whereas, on the other hand, a person is prohibited from crowding and having physical meetings. Based on this question, this research was conducted to obtain a crisis communication model and what strategies are used in communicating it. This study aims to find a COVID-19 impact crisis communication model using the local wisdom of Gending Jawa in Ngandong Village. Gending Jawa is Javanese traditional music, also known as Karawitan. This study used a qualitative descriptive method with a simulation with the leaders and members of the Jati Art Studio, community leaders/religious leaders, and village officials. The results of this study are in the form of the discovery of a COVID-19 impact crisis communication model using the local wisdom of Gending Jawa. The contribution of this research is the COVID-19 crisis communication, model whose results can be used or applied to other communities.

This is an open access article under the CC-BY-SA license.

\section{Introduction}

Coronavirus disease (COVID-19) first appeared in Wuhan, China at the end of 2019 [1][2]. COVID-19 is an unstoppable spread of the disease and has been declared a pandemic [3]. This is in line with the statement from the Head of the National Disaster Management Agency (BNPB) Doni Monardo, who said that COVID-19 had been categorized as a global pandemic. Hence, the status of COVID-19 is a non-natural disaster [4]. Non-natural disasters are disasters caused by epidemics, failure of a technology, or outbreak [5] [6]. COVID-19 is a non-natural disaster experienced by the world with a high level of fatality. This is evidenced by research conducted by Vellingiri et al. which states that the COVID-19 epidemic is a new epidemic that is sweeping the world with a high fatality rate and a faster spread than other diseases, such as SARS and MERS [7]. The COVID-19 pandemic needs to be treated seriously to reduce the spread because some victims from the Asian population are more susceptible to COVID-19 infections compared to other racial demographics. The study reinforces this research so that the handling of COVID-19 in Indonesia is carried out quickly and responsively, so as not to cause a greater disaster. Handling in reducing the spread of COVID-19 can 
be done by maintaining and strengthening social networks. The formation of this social network is basically a communication network that requires the existence of symbolic communication, cultural rules, and power relations [8], so that in this study communication is considered necessary in responding to the COVID-19 disaster because the communication network and information dissemination process was expanded during the mitigation effort [9] [10].

When disasters occur, crisis communication often arises without being predicted. COVID-19 raises crisis communication in people's lives. Crisis communication is the exchange of information and opinions from people who understand and understand in real-time [11]. Information exchange can be used with local media. The emergence of various speculations regarding COVID-19 information circulating among the public is still uncertain, so the impact of COVID-19 is getting worse. The effect of COVID-19 is very influential for public health, psychological society, the behavior of social activities, and community economic development.

The people in Ngandong Village also experienced this impact. People in Ngandong Village still rarely heed the "stay at home" implementation. Residents always carry out activities as usual, including working on building projects, in markets, in the fields, and selling around. This is due to the lack of socialization that has not been fully understood by the community. While the village community is the majority of the elderly, who are vulnerable to disease. Older people have more severe risks of COVID-19. The pre-survey conducted on 24 April 2020 obtained data that the population of Ngandong Village was approximately 1 million people, most of them were the elderly who felt uneasy due to COVID-19. This anxiety is one of the triggers for vulnerability to disease because the elderly's immune system is weaker and causes a high mortality rate. This must be addressed immediately by giving positive and entertaining messages. Media socialization is appropriate, hit, and often used by residents, namely Karawitan, in the form of Gending Jawa through the Rasa Jati Art Studio (Sanggar Seni Rasa Jati).

Media socialization with the principle of local wisdom is considered useful in handling disasters to be resilient to disasters. This is supported by research on local wisdom gending conducted by Sularso \& Maria [12] which states that musical extracurricular are useful to understand the values of local wisdom stored in musical instruments, music, song or dance, and implemented in everyday life. Other studies regarding local wisdom of the song studied by Fauzan \& Nashar [13]. The results of the study stated that the art of Terebang Gede was developed as an entertainment performance through songs that must be preserved and preserved. Nuraeni, Hakim, \& Awaliyah [14] examined local wisdom through gending. The result of the research is that there is a gending training conducted for shadow puppets accompaniment by young puppeteers in giving messages to strengthen the values of Pancasila.

Research on the topic of disaster management involving elements of art can be found in Nakagawa's study. The research proposes two aspects of disaster recovery, namely support for culture, and support through learning. Support for culture is manifested in the form of rebuilding infrastructure destroyed by disasters, such as rebuilding schools, hospitals, places of worship, art studios, and so on. Whereas support through culture, such as artistic expression, according to Nakagawa, is more important. Because it brings healing and psychological comfort, art as a tool for communication, according to Nakagawa, acts as a medium for self-expression. In the context of disaster recovery, Nakagawa believes that art must be placed on victims as a means of expression. Art plays a vital role in treating psychological; In conclusion, from Nakagawa's research, the aim of 'support for culture' is the restoration of culture itself, with 'support through culture,' the object is not culture itself, but the revival of society as a whole [15]. Nakagawa's research differs from this study, if Nakagawa offers two perspectives of discussion, namely support for culture, and support through culture, in this study we want to discuss the issue of Gending Jawa as a medium of crisis communication in the midst of the global pandemic COVID-19.

Other research related to the topic of this study is the research conducted by Clarke. Clarke's analysis addresses the issue of empathy and understanding of music culture. Empathy and music are the keywords in the study. According to Clarke, for many people, music provides the most powerful experience and has the potential to change one's life. According to him, music at the same time can increase the communicative and affective capacity so that the potential is at the same time an agent of social ties and affiliation. Clarke's empirical results test one aspect that 'passive' listening to music from a foreign culture can significantly change the cultural attitudes of listeners with high empathy 
[16]. Clarke's research results are indeed beneficial for this study because it provides an understanding that music empathically has a strong influence on forming perceptions and forming social bonds. However, in the context of crisis communication, Clarke does not explain how music is treated in disaster situations. Humanly speaking, empathy is the power to feel the status and condition of others.

Research on the topic of music and local wisdom is undoubtedly precious for this study because it is useful to obtain information on how music and local wisdom are useful in crisis communication. Research related to music and local wisdom can be found in Mulyana's research. Mulyana discussed the reality of acculturation in the Sekaten Ceremony in Yogyakarta. The method used is ethnography, by discussing language, communication, and cultural issues. The results of Mulyana's research are the symbols used in the Sekaten traditional ceremony are the result of the process of acculturation of Islam and Hinduism and Javanese philosophical values. The conclusion of the study, the Sekaten ceremony is a form of non-verbal communication in the form of symbols, artifacts of reflective value [17]. The issue of accuracy is real, at first, not related to the problem of crisis communication. Still, it needs to be understood if, in music, there is communication that makes acculturation formed. This communication process is seen so that this study can find out how the communication model is accurate, and can the model be adapted in crisis communication? In this study, this question is given emphasis.

History records, communication, and local wisdom have long been integrated into the lives of rural communities in various parts of Indonesia. In Javanese rural communities, for example, it is known as kentongan titir, which, if hammered many times in a quick tone, is a signal to villagers about the danger of flooding. [18]. Hearing the sound of a kentongan like that, the villagers were simultaneously prepared and guarded against the flood disaster. Villagers have more knowledge about local wisdom communication in a local and responsive manner [19].

The novelty of this research is compared with previous studies, namely finding a COVID-19 impact crisis communication model using local wisdom of Gending Jawa. Previous research on local wisdom but not based on Gending Jawa and to overcome natural disasters. There is Gending Jawa based research, but to socialize the values of empathy and entertainment. This research utilizes Gending Jawa as positive messages in preventing COVID-19 and realizing COVID-19 disasterresilient villages. This study aims to find a COVID-19 impact crisis communication model using the local wisdom of Gending Jawa in Ngandong Village.

\section{Theorical Framework}

\subsection{Crisis Communication Theory}

The COVID-19 disaster brought about the emergence of crisis communication. This study uses Sellnow's crisis communication theory Timothy L and Matthew W. Seeger who stated that crisis communication is an ongoing process of creating shared meaning between individuals, groups, communities, and institutions with the aim of reducing, limiting, preparing, responding to threats [18]. The community must be prepared to respond to the COVID-19 disaster following the principles of crisis communication. Crisis communication has three main principles [20] [21], namely: (1) delivering messages quickly and accurately. The news that was conveyed rapidly gave the media a chance about what was happening. The right word means the message is right targeted to the community. This research provides news for the prevention of COVID-19 transmission quickly and accurately to the target community in Ngandong Village through local media, namely Gending Jawa; (2) Consistent in conveying the contents of the message even though different sources. The message content is delivered consistently based on health protocols from the government; (3) openness has two interpretations. Namely, the people who read the message are reluctant to provide comprehensive information and the people who deliver the news give complete details. In this study, the delivery of messages provides comprehensive information about risk reduction due to the COVID-19 crisis.

\subsection{Local Media}

Local media or often referred to as regional media such as kentongan, gending, gamelan which can adjust the function according to the purpose [22] [23]. The function of local media in crisis communication, namely: 1) providing information in the form of COVID-19 disaster; 2) educating 
the public for the prevention of COVID-19 by living a healthy life, including correct handwashing procedures; 3 ) persuading or influencing the community, among others by inviting the public not to go home, diligently washing their hands, always keeping a distance; 4) entertaining the public, one of them is by creating unique songs and still inserting invitations to prevent transmission of COVID19. The function of the local media is to reduce the spread of COVID-19 so that there are no additional casualties. Local media is closely related to cultural values that can be used as a reference for the community in behaving to avoid COVID-19.

\subsection{Local Wisdom}

The COVID-19 disaster took many casualties and high losses because of the rapid spread [24]. One way to avoid the number of victims is to instill cultural values. Culture is believed to be able to embrace disaster, cultural knowledge produced by society is built on aesthetic rationality that is created from time to time. The community prefers to look at cultural values that must be considered to increase trust and reduce anger in disasters.

Culture is undoubtedly closely related to local wisdom. Local wisdom is local cultural values in the form of community activities that can be used as a life control system and answer the problems faced [25], [26], [27]. Local wisdom is an integral part because local knowledge contains social norms and values in regulating, developing, and maintaining a balance between nature, human needs, and lifestyle [28] [29]. Norms, social values, ethics are fundamental to be developed and explained to the next generation as a guide to cultural life in society. Local wisdom as a guide to cultural life is applied in the prevention of COVID-19, among others, by utilizing Gending Jawa, which implies positive messages in carrying out a life amid the COVID-19 pandemic.

\section{Method}

This research uses descriptive qualitative method with simulation. This research is located in the village of Ngandong, Gantiwarno, Klaten, Central Java. The object of this research is COVID-19 crisis communication based on local wisdom of Gending Jawa. The subjects of this study were all those involved in handling COVID-19 crisis communication in Ngandong Village. Data collection techniques carried out by interview, observation, Focus Group Discussion (FGD), documentation, and simulation. FGD participants and simulations, namely: leaders and members of the Rasa Jati Art Studio, community leaders/religious leaders, and village officials.

Qualitative data analysis techniques refer to Davis [30], which is done by (1) data collection at the time of pre-simulation, when-simulation, and post-simulation. The process of collecting data in this study includes data from interviews, observations, documentation and literature studies from the subject or object of research at Rasa Jati Art Studio Ngandong Village; (2) Data reduction in this research is the process of sorting, focusing and simplifying the data that has been collected. This process intends to sharpen and direct the data so as to facilitate the presentation of data and drawing conclusions. The process in this study since the creation of Gending Jawa that contained messages of COVID-19 prevention to implementation through a Gending Jawa simulation at the Rasa Jati Art Studio with the community; (3) Presentation of the data is made to mean the data and interpretation in accordance with the reality that occurs in accordance with the theory used as a basis for research. Presentation of data about the meaning of the message in the Gending Jawa created by the Rasa Jati Art Studio and data on community behavior in the prevention of COVID-19; (4) Drawing conclusions is the final process of data analysis. Conclusions are drawn in this study refer to the results of existing studies associated with the theory used in this study. The results of the study concluded that the COVID-19 impact crisis communication model used local wisdom of Gending Jawa.

\section{Results and Discussion}

The results of the study found various information that could formulate the COVID-19 crisis impact communication model using local wisdom of Gending Jawa. Researchers conducted interviews with Ngandong Village people aged 33 to 66 years about the social, economic, and psychological impacts during the COVID-19 pandemic. 50\% of the informants work as private employees, this data can be seen in Figure 1. 


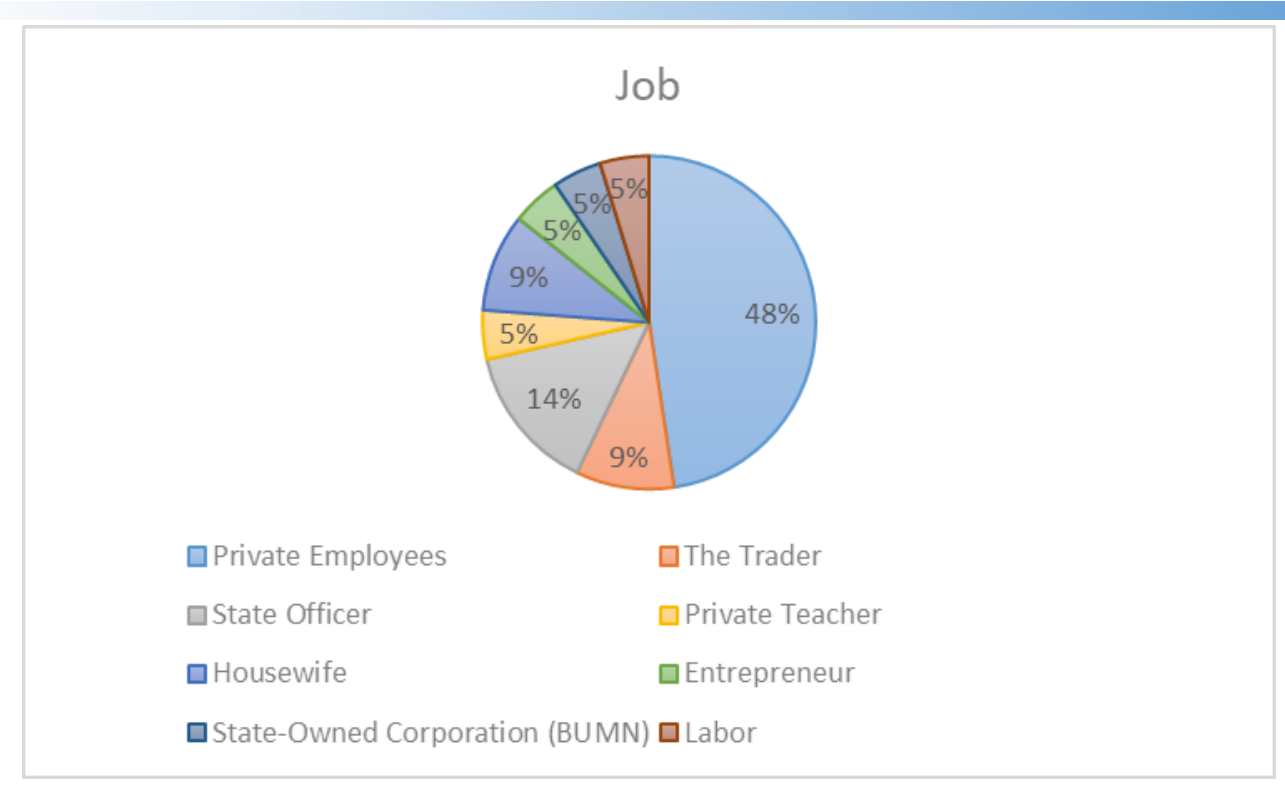

Fig. 1 Job Percentage

Source: Research Documents, 2020

Other informants work as traders $10 \%$, civil servants $15 \%$, housewives $10 \%$, private teachers, entrepreneurs, BUMN, and laborers by 5\%. During the pandemic, many informants did not work, so they only stayed with their families at home, but some were still working to survive. One informant said:

"In this village, we are still close together with friends and neighbors. Still, because of this corona, the social impact that we feel at this time is that we cannot associate anymore, are not free to go out of the house, like going to the market, cannot tell stories with neighbors, I cannot go to houses of worship, relatives. I want to leave the house feeling scared because other people are wary of carrying the virus if forced to keep their distance" (CSW, May 4, 2020)

The social impact of COVID-19 is felt. Namely, the sense of fear and vigilance thought by the people of Ngandong Village when chatting with neighbors. Excessive anxiety and attention do not just stop at social impacts, but there are very substantial impacts, namely economic impacts. The economy at the time of the COVID-19 pandemic was very turbulent, due to reduced income and even no income to meet current needs.

"Right now, the needs of the family are, huge but the small income plus all the prices of necessities go up. I am getting dizzy thinking about going to a business, especially, try side businesses are also very quiet. Because the need now is not to eat, electricity, water, but I also have to buy vitamins to maintain health and endurance. The point is that if you have economic problems, you have to be good at managing expenses, and you have to adjust to the income you have saved" (PS, May 4, 2020).

Some Ngandong villagers continue to work during this pandemic, despite feeling the concern of COVID-19. Arising excessive feelings of worry and fear of the people due to social and economic impacts will affect the mind, causing psychological effects, such as natural stress and more susceptible to disease. The psychological impact of the Ngandong Village community was experienced by one of the informants:

"I am very stressed at work from home all the time, plus the children also have tasks to be guided, there are other homework assignments. I get tired and continue to feel a little emotional to teach children the responsibility. Mind you, when will this pandemic stop, I'm going to be depressed for a long time. Worried also the children who keep complaining said bored. Well, what do I do, I'm also confused and worried" (PRDN, May 4, 2020).

Villagers make various efforts so that the community can feel calm but alert. The villagers also need entertainment. The village has a Javanese arts and culture studio, Rasa Jati, which is equipped with gamelan instruments, which are often used for training and are often considered by the 
community members when there are weddings, village cleanings, or other village events. Researchers see this as the potential to create Gending Jawa works of art as a communication medium for the COVID-19 disaster that can calm and entertain residents. The studio owner created a genre that has a positive message meaning in avoiding COVID-19 with the title "Corona Virus", Figure 2.

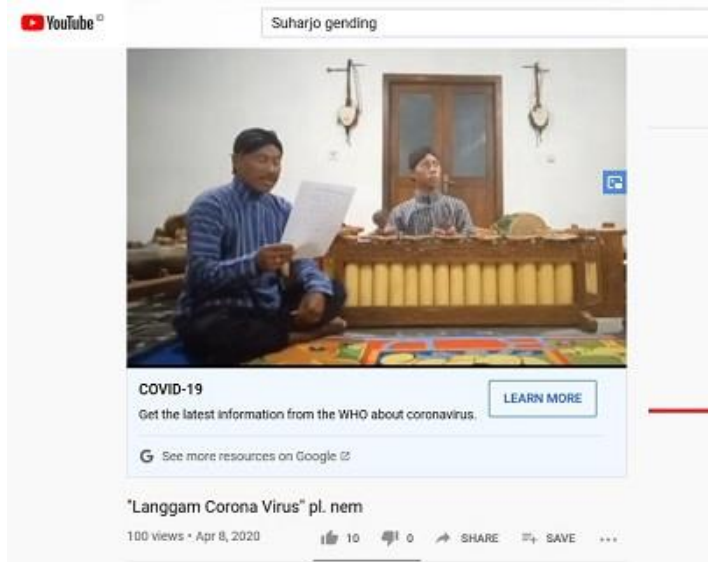

Fig. 2 Gending Jawa "Langgam Corona Virus"

Source: Youtube, 2020

Gending Jawa with the title "Corona Virus" is popularized by Rasa Jati Art Studio and has been uploaded via Youtube, which can be accessed at https://www.youtube.com/watch?v=7kaQVmHzj-o and spread through the WhatsApp group. Gending Jawa is performed by the wiraswara (male singer) accompanied by Javanese gamelan music, which implies a positive message in the lyrics of gending. The songs are seen in figure 3.

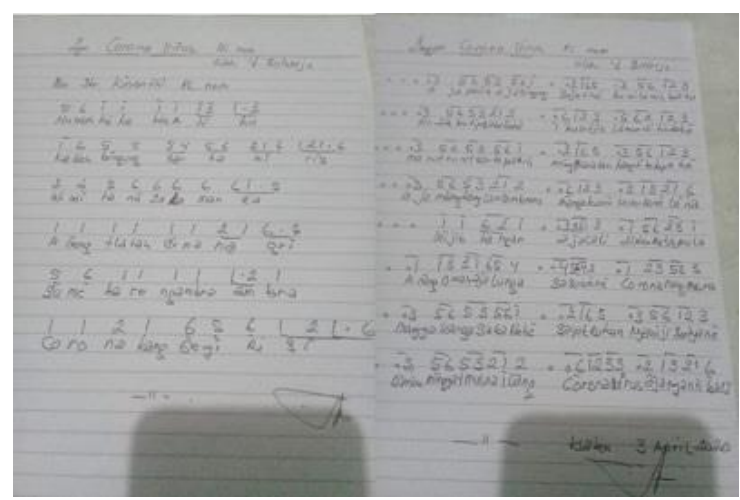

Fig. 3 Original Manuscript Song Lyrics "Corona Virus"

Source: Documentation from the Gending Creator (Suharjo), 2020

The lyrics of Gending Jawa Figure 3 are interpreted as a feeling of the whole of Indonesian society and even a feeling of the world that arises in fear and tilt because Corona is spreading rapidly. The community was asked not to be confused, not panic, not careless, not rebellious, and asked to remain orderly in accordance with all the regulations that have been set. Keep washing your hands, living clean, staying at home, and not having to leave the house while Corona is still there. The Gending Jawa also invites the community to work together in helping to unravel Corona's distribution.

The studio's creativity by creating Gending Jawa is considered to convey positive information, educate, persuade, and entertain the public during the COVID-19 pandemic. This statement is following the results of researchers' interviews with one of the people who enjoy Gending Jawa:

"After listening to the Gending Jawa chanting, positive information delivered was about the health protocol reflected in avoiding the Corona Virus transmission. If there are lessons learned, too, avoid COVID by thinking positively and not panning and being reckless, washing your hands will avoid COVID. We are also invited to keep abreast of government regulations, 
diligently wash hands, and stay home. The invitation that was delivered felt smooth and familyfriendly, as well as the Javanese chanting, the creator of the music, the musicians, the interesting gamelan and very entertaining during this pandemic" (SPD, May 4, 2020).

Based on the response from the informant that the community understood the risk of transmission of COVID-19, and the city could take messages from the Gending Jawa delivered by Rasa Jati Art Studio. The town very much accepts the delivery of messages through WhatsApp Group and Youtube because it is following health protocols that encourage people not to hold meetings face to face. Words through local wisdom gending, people can take positive lessons, as evidenced by the response of informants through the Google form circulated by researchers

The results of the study found communication models ranging from making Gending Jawa messages, delivering gending messages through WhatsApp and Youtube groups or in a limited studio, and receiving messages by the public about COVID-19 crisis communication through local wisdom of Gending Jawa, see figure 4.

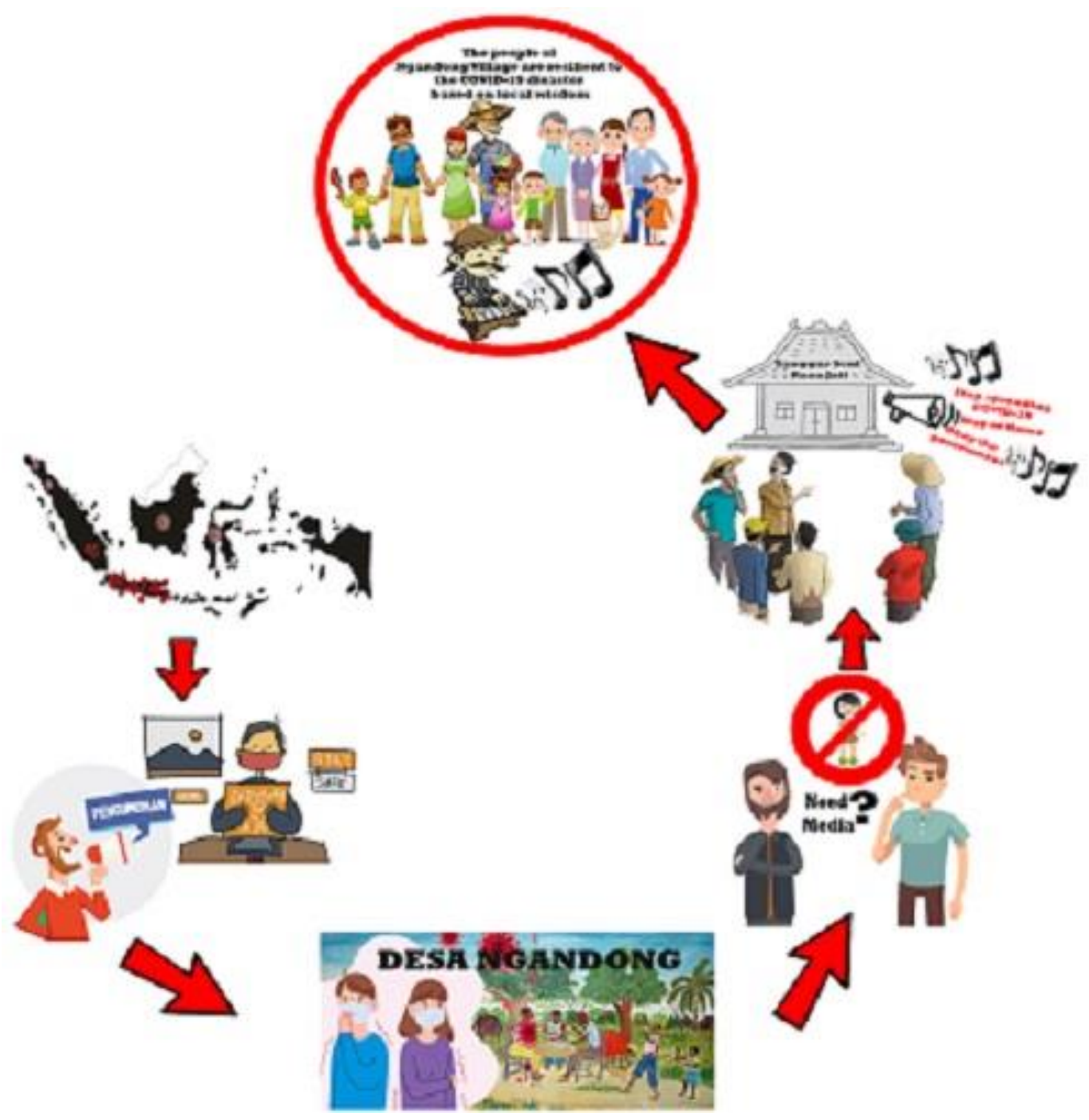

Fig. 4 COVID-19 Impact Crisis Communication Model based on Gending Jawa Local Wisdom Sumber: Research Documents, 2020

Figure 4 explains that the beginning of the COVID-19 disaster in Indonesia in early March 2020. The process of communication in the community began to talk about COVID-19, its characteristics aggressively, and its effects since the President announced that there were Indonesians infected with COVID-19. Several government policies began to be implemented with health protocols to reduce transmission and spread of COVID-19. The people of Ngandong Village, Bukawarno Subdistrict, Klaten Regency started to feel anxieties which caused the attitudes 
and behavior of the people to become anxious. To overcome various community concerns, there is an art figure in the village who took the initiative to make persuasive messages according to the health protocol to reduce the spread of COVID-19 through local media, namely Gending Jawa. Gending created in the form of the Corona Virus style was tested (simulation) at Rasa Jati Art Studio. The simulation results show a positive response that messages through the Corona Style can provide information, entertainment, education, and influence the community so that the city meets the health protocol according to the contents of the Corona Style. The impact of community compliance in Ngandong Village has not been infected with COVID-19, and the community feels resilient in the face of the COVID-19 disaster.

The crisis communication model of COVID-19 impact based on local wisdom of Gending Jawa is following the theory of crisis communication that creates and carries out activities that produce new meaning when disasters occur [31] [32]. Crisis communication is considered very important in the current COVID-29 emergency. Effective crisis communication becomes a fundamental component in the concepts of mitigation, disaster management, and disaster risk reduction. Crisis communication in COVID-19 disaster is used as a form of communication when a COVID-19 crisis occurs, starting with suggestions from related parties, harmonious acceptance and decision-making processes, discussion about the steps that must be taken in adjusting messages with the community, and new actions which are done to fill the gap [33].

The new action taken to fill the gap is to activate the Rasa Jati Art Studio to create Gending Jawa based on local wisdom in the face of the COVID-19 pandemic. The meaning arising from the activities carried out, namely: 1) the emergence of messages in the form of positive information in the form of COVID-19; 2) gending is used to entertain the public by using gending; 3) educate the public by giving things done to reduce the spread of COVID-19 by washing hands and living healthy; 4) influence the community by encouraging the community to keep abreast of government regulations by staying at home and not going home. This is in accordance with the function of local media through Gending Jawa in the community to entertain, educate, influence, and entertain the community by utilizing culture that can be spread to the younger generation [34] [35]. In addition, local media can be used to increase the economic value of the community. This is in line with research conducted by Sugianto [36] and Antlöv [37], which states that the role of villages can support village programs and become the main capital for village development, supported by contributions from local communities and the impact on the community's economy. Ngandong Village can take advantage of the existence of the Rasa Jati Art Studio in improving the community's economy through means of entertainment in local community events, such as weddings, village cleansing, and other events.

Local media is expected to help the community to provide mental support to the surrounding community because mental support is important for people who are experiencing a disaster so as not to harm themselves and others. The public response to feeling at home is similar to research conducted by the Inter-Agency Standing Committee (IASC), which states that symptoms of stress to depression will arise if only at home [38] [39]. This is in line with research conducted by Marthoenis, which states that mental support due to stress must be done so that mental conditions return clear and have no impact on themselves so that health is recovered [40] [41]. Early support of sufficient stress reduction must be carried out to reduce the vulnerability of the disease, which can be done by seeking entertainment such as listening to Gending Jawa by implying a positive message. Positive messages affect the mind; thoughts affect the heart and the heart influences actions. This crisis communication model is valid for the majority of people who like Gending Jawa to be important in realizing community resilience, reducing stress, and avoiding COVID-19 disease.

\section{Conclusion}

This study found a COVID-19 impact crisis communication model based on Gending Jawa's local wisdom. This research contributes to the COVID-19 disaster communication model based on local knowledge of Gending Jawa in COVID-19 prevention and provides positive messages for the 
people of Ngandong Gantiwarno Village in Central Java to stay at home, maintain health, and increase body immunity to avoid COVID- 19 The economic value that can be generated from this research is to increase the productivity of the Rasa Jati Art Studio as a means of entertainment in local community events, such as weddings, design clean, and other activities. The social value given is the realization of the regeneration process of Javanese cultural figures, especially Gending Jawa to the younger generation, as well as establishing togetherness in overcoming the COVID-19 disaster through the Rasa Jati Art Studio group.

\section{Acknowledgment}

The researchers are grateful to the Rasa Jati art Studio in Ngandong Gantiwarno for helping with this research, the researcher also wants to thank the informants, who provided a lot of information for this research, and especially research Institute and Community Service (LPPM) of Universitas Pembangunan Nasional "Veteran" Yogyakarta which has funded this research.

\section{References}

[1] E. E. Brown, S. Kumar, T. K. Rajji, B. G. Pollock, and B. H. Mulsant, "Anticipating and Mitigating the Impact of COVID-19 Pandemic on Alzheimer's Disease and Related Dementias," Am. J. Geriatr. Psychiatry, pp. 1-10, 2020.

[2] B. Robson, "COVID-19 Coronavirus spike protein analysis for synthetic vaccines, a peptidomimetic antagonist, and therapeutic drugs, and analysis of a proposed achilles' heel conserved region to minimize probability of escape mutations and drug resistance," Comput. Biol. Med., vol. 121, p. 103749, 2020.

[3] A. Remuzzi and G. Remuzzi, "COVID-19 and Italy: what next?," Lancet, vol. 395, no. 10231, pp. 1225-1228, 2020.

[4] L. S. Rahayu, "Kepala BNPB: Virus Corona Pandemi Global, Statusnya Bencana Non-alam," detikNews, 2020. [Online]. Available: https://news.detik.com/berita/d-4939091/kepala-bnpb-viruscorona-pandemi-global-statusnya-bencana-non-alam. [Accessed: 09-Apr-2020].

[5] A. Z. Rahman, "KAJIAN MITIGASI BENCANA TANAH LONGSOR DI KABUPATEN BANJARNEGARA," GEMA PUBLICA J. Manaj. DAN Kebijak. PUBLIK, vol. 1, no. 1, pp. 1-14, 2015.

[6] R. Arianto, H. L. H. S. Warnars, F. L. Gaol, and A. Trisetyarso, "Mining Unstructured Data in Social Media for Natural Disaster Management in Indonesia," in 2018 Indonesian Association for Pattern Recognition International Conference (INAPR), 2018, pp. 192-196.

[7] B. Vellingiri et al., "COVID-19: A promising cure for the global panic," Sci. Total Environ., vol. 725, no. 138277 , pp. 1-18, 2020.

[8] A. J. Pesurnay, "Local Wisdom in a New Paradigm: Applying System Theory to the Study of Local Culture in Indonesia," IOP Conf. Ser. Earth Environ. Sci., vol. 175, p. 012037, Jul. 2018.

[9] R. R. D. Juneza and D. Purworini, "Respon Para Disabilitas terhadap Komunikasi Krisis BPBD (Badan Penanggulangan Bencana Daerah) dan Tim SAR Klaten Tahun 2016," J. Profetik, vol. 9, no. 1, pp. 8096, 2016.

[10] M. Douglas, S. V. Katikireddi, M. Taulbut, M. McKee, and G. McCartney, "Mitigating the wider health effects of covid-19 pandemic response," BMJ, p. m1557, Apr. 2020.

[11] E. M. Abrams and M. Greenhawt, "Risk Communication During COVID-19," J. Allergy Clin. Immunol. Pract., pp. 1-4, 2020.

[12] P. Sularso and Y. Maria, "UPAYA PELESTARIAN KEARIFAN LOKAL MELALUI EKSTRAKURIKULER KARAWITAN DI SMP NEGERI 1 JIWAN TAHUN 2016,” J. Citizsh. J. Pendidik. Pancasila dan Kewarganegaraan, vol. 5, no. 1, pp. 1-12, 2017.

[13] R. Fauzan and Nashar, “ "Mempertahankan Tradisi , Melestarikan Budaya ’ (Kajian Historis dan Nilai Budaya Lokal Kesenian Terebang Gede di Kota Serang )," J. Candrasangkala, vol. 3, no. 1, pp. 1-9, 2017. 
[14] A. Nuraeni, S. Al Hakim, and S. Awaliyah, "PENGUATAN NILAI-NILAI PANCASILA MELALUI KEGIATAN SENI KARAWITAN 'MAREM GAYENG' DESA PAGELARAN KABUPATEN MALANG,” J. Online Univ. Negeri Malang, 2015.

[15] S. Nakagawa and K. Suwa, "A cultural approach to recovery assistance following urban disasters," City, Cult. Soc., vol. 1, no. 1, pp. 27-36, Mar. 2010.

[16] E. Clarke, T. DeNora, and J. Vuoskoski, "Music, empathy and cultural understanding," Phys. Life Rev., vol. 15, pp. 61-88, Dec. 2015.

[17] A. Mulyana, "Sekaten Tradition: The Ritual Ceremony in Yogyakarta as Acculturation Reality of Javanese Culture in Indonesia," Int. J. Humanit. Soc. Sci. Stud., vol. 4, no. 2, p. 50, Sep. 2017.

[18] P. Lestari, R. Ritonga, P. Ruliana, and C. C. B. Barus, "Disaster Communication Uses Field Training Exercise Simulation as an Important Aspect of Disaster Risk Reduction," J. Komun. Malaysian J. Commun., vol. 36, no. 24, pp. 166-186, 2020.

[19] J. W. R. Genilo, "Communication and the Construction of Local Knowledge in Thai Rice Farming Villages," Millenn. Asia, vol. 1, no. 2, pp. 197-214, 2017.

[20] N. M. Prastya, "Komunikasi Krisis di Era New Media dan Sosial Media," J. Komun., vol. 6, no. 1, pp. $1-20,2011$.

[21] L. Tyler, "Towards a postmodern understanding of crisis communication," Public Relat. Rev., vol. 31, no. 4, pp. 566-571, Nov. 2005.

[22] I. A. Yusuf, "Media Lokal dalam Konstelasi Komunikasi Politik di Daerah," J. Ilmu Sos. dan Ilmu Polit., vol. 14, no. 3, pp. 297-316, 2011.

[23] M. E. Septiana et al., "Disaster Education Through Local Knowledge in Some Area of Merapi Volcano," IOP Conf. Ser. Earth Environ. Sci., vol. 271, p. 012011, Jul. 2019.

[24] P. J. Lillie et al., "Novel coronavirus disease (Covid-19): The first two patients in the UK with person to person transmission," J. Infect., no. xxxx, pp. 13-15, 2020.

[25] U. Fajarini, "Peranan Kearifan Lokal Dalam Pendidikan Karakter," SOSIO Didakt. Soc. Sci. Educ. J., vol. 1, no. 2, 2014.

[26] M. Khusniati, "Model Pembelajaran Sains Berbasis Kearifan Lokal Dalam Menumbuhkan Karakter Konservasi," Indones. J. Conserv., vol. 3, no. 1, pp. 67-74, 2014.

[27] D. A. Marhayani, "Development of Character Education Based on Local Wisdom in Indegenous People Tengahan Sedangagung," JETL (Journal Educ. Teach. Learn., vol. 1, no. 2, p. 66, Sep. 2016.

[28] M. J. Pattinama, "Pengentasan Kemiskinan Dengan Kearifan Lokal (Studi Kasus Di Pulau BuruMaluku Dan Surade-Jawa Barat)," Makara, Sos. Hum., vol. 13, no. 1, pp. 1-12, 2009.

[29] H. B. Patriadi, M. Z. A. Bakar, and Z. Hamat, "Human Security in Local Wisdom Perspective: Pesantren and its Responsibility to Protect People," Procedia Environ. Sci., vol. 28, pp. 100-105, 2015.

[30] N. W. Davis and B. B. Meyer, "Qualitative Data Analysis: A Procedural Comparison,” J. Appl. Sport Psychol., vol. 21, no. 1, pp. 116-124, Feb. 2009.

[31] J. Kurniawati, "Komunikasi krisis di era digital," INTELEKTIVA J. Ekon. Sos. Hum. Komun., vol. 1, no. 2, pp. 50-61, 2019.

[32] M. W. Seeger, "Best Practices in Crisis Communication: An Expert Panel Process," J. Appl. Commun. Res., vol. 34, no. 3, pp. 232-244, Aug. 2006.

[33] C. Fearnley, A. E. G. Winson, J. Pallister, and R. Tilling, "Volcano Crisis Communication: Challenges and Solutions in the 21st Century," Adv. Volcanol., no. January, pp. 1-14, 2015.

[34] G. Aprinta, "Fungsi Media Online Sebagai Media Literasi Budaya Bagi Generasi Muda," J. Messenger, vol. 5, no. 1, pp. 16-30, 2013.

[35] K. Hastuti and K. Mustafa, "A method for automatic gamelan music composition," Int. J. Adv. Intell. Informatics, vol. 2, no. 1, 2016. 
[36] A. Sugianto, "Kajian Potensi Desa Wisata Sebagai Peningkatan Ekonomi Masyarakat Desa Karang Patihan Kecamatan Balong Ponorogo," Ekuilibrium J. Ilm. Bid. Ilmu Ekon., vol. 11, no. 1, p. 56, 2016.

[37] H. Antlöv, A. Wetterberg, and L. Dharmawan, "Village Governance, Community Life, and the 2014 Village Law in Indonesia," Bull. Indones. Econ. Stud., vol. 52, no. 2, pp. 161-183, May 2016.

[38] Inter-Agency Standing Committee (IASC), "Catatan tentang aspek kesehatan jiwa dan psikososial wabah," Geneva, 2020.

[39] S. Abramowitz and A. Kleinman, "Humanitarian intervention and cultural translation: a review of the IASC Guidelines on Mental Health and Psychosocial Support in Emergency Settings," Intervention, vol. 6, no. 3, pp. 219-227, Nov. 2008.

[40] E. Amalia, I. Arum L, and S. Kusdaryono, "Training of Trainer (TOT) Dukungan Psikologis dan Self Empowerment Paska Bencana Bagi Staf dan Mahasiswa Fakultas Kedokteran Universitas Mataram,” J. Pengabdi. Magister Pendidik. IPA, vol. 1, no. 2, 2019.

[41] M. Marthoenis, S. Yessi, M. C. Aichberger, and M. Schouler-Ocak, "Mental health in Aceh Indonesia: A decade after the devastating tsunami 2004," Asian J. Psychiatr., vol. 19, pp. 59-65, Feb. 2016. 